\title{
Dr. Aurelio Miró Quesada Sosa In memoriam
}

Pocas semanas antes de la fecha en que dejara de existir el Dr. Aurelio Miro Quesada Sosa, nuestra Casa de Estudios le tributo un merecido homenaje, en razón de su notable magisterio, de la importancia de su obra intelectual y de la distinguida gestión que cumplió como Decano de la Facultad de Letras y Ciencias Humanas y como Rector de la Universidad Nacional Mayor de San Marcos. En aquella ceremonia, el discurso que pronunció el Dr. Miró Quesada, puso en evidencia que su pensamiento y acción tuvieron el permanente impulso y sustento de su profundo e inmenso amor a la Universidad de San Marcos. Este rasgo distintivo de la manera de ser y de actuar del Dr. Aurelio Miró Quesada Sosa y de todos los auténticos sanmarquinos, permite explicar cómo es que su existencia personal logra trascender sus propios límites y, en el contexto del quehacer académico universitario, adquirir pleno sentido y proyeccion al servicio a la comunidad de todos los seres humanos.

A mi juicio, ese profundo e inmenso amor a la Universidad de San Marcos es el hecho más significativo en la tarea definitoria de la conducta paradigmática del Dr. Aurelio Miró Quesada Sosa como maestro universitario y ciudadano. La indicada actitud se traduce en el genuino compromiso personal para contribuir, con creatividad y honestidad intelectual, al logro de los grandes ideales expresados en los fines y objetivos de nuestra Universidad. En razón de esos méritos la comunidad académica constituida por profesores y alumnos de la Facultad de Letras y Ciencias Humanas ha estimado el alto honor de dedicar este número de la Revista LETRAS a la memoria de tan insigne maestro. 
Creo que la mejor manera de honrar la memoria de quienes como el Dr. Aurelio Miró Quesada Sosa dedicaron su pensamiento y acción al desarrollo académico e institucional de la Universidad Nacional Mayor de San Marcos, consiste en renovar a través de la formación profesional, la investigación y la proyección social, nuestra promesa de continuar realizando con el aura de su ejemplo los mayores esfuerzos para, contribuir al desarrollo organizacional y a la promoción de los valores académicos que distinguen la tradición y son el signo del futuro de nuestra Casa de Estudios.

Lima, diciembre de 1998

Dr. GILBERTO BUSTAMANTE GUERRERO

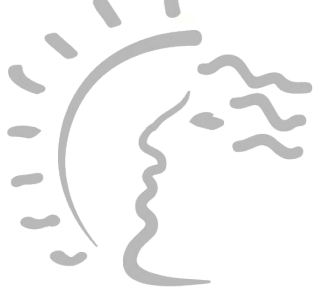

Decano 